\title{
Pengaruh Pendapatan Asli Daerah dan Flypapaer Effect Terhadap Perilaku Oportunistik Penyusun Anggaran
}

\author{
Anita De Grave ${ }^{1 *}$, Raja Vanaldo Boang Manalu' ${ }^{2}$, Rein J. Wekan ${ }^{3}$ \\ 1, 2Sekolah Tinggi Ilmu Ekonomi Balikpapan, Kalimantan Timur, Indonesia \\ ${ }^{3}$ Pegawai Sekretariat DPRD Kabupaten Maluku Barat Daya, Maluku, Indonesia \\ 'anita@stiebalikpapan.ac.id; ${ }^{2}$ rvanaldo@stiebalikpapan.ac.id; ${ }^{3}$ reinwekan@yahoo.com \\ ${ }^{*}$ Penulis korespondensi
}

\begin{abstract}
This study aims to test and analyze the effect of local revenue and flypaper effect on the opportunistic behavior of budget makers. The data used in this research is panel data from eleven districts/ cities in Maluku province from 2014 to 2020. The analysis method used is panel data regression analysis. The results showed that: (1) Local Own Revenue has a positive and significant effect on the Opportunistic Behavior of Regency/City Budget Formers in Maluku. This means that the higher the District/City Original Revenue, the higher the Opportunistic Behavior of Budget Compilers; (2) The Flypaper Effect has a positive and significant effect on the Opportunistic Behavior of Regency/ City Budget Formers in Maluku. This means that the higher the occurrence of flypaper effect in regencies/cities in Maluku, the higher the opportunistic behavior of budget makers; and (3) Simultaneously the Regional Original Income and the Flypaper Effect influence the Opportunistic Behavior of Regency/City Budget Formers in Maluku.
\end{abstract}

Keywords: Local Own Income, Flypaper Effect, Opportunistic Behavior, The government budget

\begin{abstract}
Abstrak
Penelitian ini bertujuan untuk menguji dan menganalisis pengaruh Pendapatan Asli Daerah dan Flypaper Effect terhadap Perilaku Oportunistik Penyusun Anggaran. Data yang digunakan dalam penelitian ini adalah data panel 11 kabupaten/kota di provinsi Maluku tahun 2014 sampai 2020. Metode analisis yang digunakan yaitu analisis regresi data panel. Hasil penelitian menunjukkan bahwa: (1) Pendapatan Asli Daerah berpengaruh positif dan signifikan terhadap Perilaku Oportunistik Penyusun Anggaran Kabupaten/Kota di Maluku. Hal ini bermakna bahwa semakin tinggi Pendapatan Asli Daerah Kabupaten/Kota akan mendorong semakin tingginya Perilaku Oportunistik Penyusun Anggaran; (2) Flypaper Effect berpengaruh positif dan signifikan pada Perilaku Oportunistik Penyusun Anggaran Kabupaten/Kota di Maluku. Hal ini bermakna bahwa semakin tinggi terjadinya Flypaper Effect pada Kabupaten/Kota di Maluku, maka akan menyebabkan Perilaku Oportunistik Penyusun Anggaran yang semakin tinggi; dan (3) Secara simultan Pendapatan Asli Daerah dan Flypaper Effect memengaruhi terjadinya Perilaku Oportunistik Penyusun Anggaran Kabupaten/Kota di Maluku.
\end{abstract}

Kata Kunci: Pendapatan Asli Daerah, Flypaper Effect, Perilaku Oportunistik, Anggaran Pemerintah 


\section{PENDAHULUAN}

Seiring dengan pemberlakuan kebijakan Otonomi Daerah sebagaimana termuat dalam Undang-Undang Nomor 22 Tahun 1999 tentang Pemerintahan Daerah terakhir UndangUndang Nomor 23 Tahun 2014, maka setiap daerah diberikan kewenangan dan tanggung jawab untuk mengelola daerahnya masing-masing di dalam memenuhi kebutuhan masyarakat dan kepentingan pemerintahan daerahnya. Namun, dalam praktiknya pelaksanaan otonomi daerah belum berjalan dengan baik. Hal ini terlihat dari Anggaran Pendapatan dan Belanja Daerah yang ada pada masing-masing daerah otonomi, dimana dana perimbangan merupakan pendapatan daerah yang memiliki porsi yang sangat besar jika dibandingkan dengan Pendapatan Asli Daerah (PAD). Kondisi ini menunjukkan bahwa dana transfer dari pemerintah pusat masih menjadi sumber pendapatan yang mendukung pembiayaan pengeluaran pemerintah daerah. Transfer antar pemerintah merupakan fenomena umum yang terjadi di semua negara di dunia terlepas dari sistem pemerintahannya dan bahkan sudah menjadi ciri yang paling menonjol dari hubungan keuangan antara pusat dan daerah. Tujuan utama implementasi transfer adalah untuk menginternalisasikan eksternalitas fiskal yang muncul lintas daerah, perbaikan sistem perpajakan, koreksi ketidakefisienan fiskal, dan pemerataan fiskal antar daerah.

Berjalan tidaknya kebijakan otonomi daerah tidak hanya dapat dilihat dari seberapa besar daerah akan memperoleh dana perimbangan, tetapi hal tersebut harus diimbangi dengan sejauh mana instrumen atau sistem pengelolaan keuangan daerah mampu memberikan nuansa manajemen keuangan yang lebih adil, rasional, transparan, partisipatif, dan bertanggung jawab. Kewenangan besar legislatif yang diberikan oleh undang-undang membuahkan kekuatan besar yang justru dihadapkan ke eksekutif. Akibatnya eksekutif akan lebih difensif, berusaha mempertahankan eksistensinya dengan memanfaatkan keunggulan yang dimilikinya. Pemahaman eksekutif terhadap birokrasi dan administrasi, serta seluruh aturan dan perundang-undangan yang melandasinya ditunjang hubungan langsung dengan masyarakat yang telah berlangsung dalam waktu lama mengakibatkan penguasaan informasi eksekutif lebih baik dari pada legislatif (Megasari, 2015).

Pelaksanaan otonomi daerah memberi kewenangan kepada daerah untuk menggali potensi pendapatannya yang terdiri dari dua komponen utama yakni Pendapatan Asli Daerah (PAD) dan Dana Perimbangan. Pendapatan Asli Daerah merupakan sumber pendapatan daerah yang berasal dari kegiatan ekonomi daerah itu sendiri. Pendapatan Asli Daerah (PAD) merupakan salah satu pilar kemandirian suatu daerah. Desentralisasi yang diberikan kepada pemerintah daerah di dalam mengelola daerahnya secara mandiri akan memberikan peluang dan kesempatan untuk melakukan perilaku menyimpang oleh pihak-pihak yang berwenang seperti adanya Flypaper Effect. Fenomena Flypaper Effect membawa implikasi lebih luas bahwa transfer akan meningkatkan belanja pemerintah daerah yang lebih besar daripada penerimaan transfer itu sendiri (Turnbull dalam Megasari, 2015).

Flypaper Effect terjadi apabila pemerintah daerah merespons lebih besar dalam 
pengalokasian belanja daerah bila penerimaan dana perimbangan meningkat dibanding dengan peningkatan pengeluaran daerah jika terjadi peningkatan Pendapatan Asli Daerah (PAD). Terjadinya Flypaper Effect mengindikasikan bahwa adanya transfer DAU dari pemerintah pusat, maka pemerintah daerah akan berupaya agar transfer yang diberikan pada periode berikutnya tetap sama atau masih tetap besar atau dapat dikatakan bahwa seharusnya pemberian transfer DAU oleh pemerintah pusat akan menstimulan atau mendorong peningkatan kemandirian daerah, akan tetapi direspons lain oleh pemerintah daerah (daerah tidak lebih mandiri malahan sangat bergantung pada transfer pemerintah pusat). Flypaper Effect juga menunjukkan bahwa pemerintah daerah melakukan pemborosan anggaran berkaitan dengan dana transfer dari pemerintah pusat. Secara logika fenomena ini dapat disimulasikan apabila seseorang mendapat penghasilan dari pekerjaan yang diperolehnya maka akan menimbulkan kecenderungan untuk melakukan penghematan dalam pengeluarannya, sedangkan apabila seseorang memperoleh penghasilan dari bonus yang diberikan kepadanya maka kecenderungan yang terjadi bukan penghematan yang dilakukan namun pemborosan. Begitu halnya dengan yang terjadi kepada pemerintah daerah dalam pengelolaan dana transfer dari pusat yang lebih boros pengeluarannya bila dibandingkan dengan penghematan pengeluaran yang berasal dari Pendapatan Asil Daerah (PAD).

Permasalahan pada penyusunan anggaran timbul ketika pihak-pihak yang terlibat berupaya untuk memanfaatkan peluang agar kepentingan pribadi dan kelompoknya dapat diakomodir dalam APBD (Raghunandan et al, 2012 dan Suryarini, 2012). Kebijakan anggaran menjadi ajang perebutan kepentingan oleh berbagai pihak, baik pemerintah, legislatif, partai politik, pengusaha, organisasi masyarakat, maupun rakyat kecil (Sujaie, 2013). Berbagai modus perilaku oportunistik yang sering terjadi seperti menetapkan alokasi anggaran yang dimodifikasi untuk memenuhi kepentingan politik dan kepentingan individu, memasukkan usulan proyek-proyek besar yang menguntungkan salah satu pihak dalam perencanaan anggaran, serta sikap cenderung lebih memperjuangkan realisasi penetapan anggaran atas proyek- proyek yang mudah dikorupsi dengan harapan mendapatkan kompensasi fee project yang cukup besar (Jumaidi, 2014).

Penelitian Sujaie (2013) menunjukkan bahwa praktek perilaku oportunistik eksekutif dalam kebijakan anggaran terjadi karena dua faktor pendorong: Pertama, anggapan bahwa eksekutif merupakan pelaksana semua fungsi pemerintah daerah yang telah berhubungan langsung dengan masyarakat dalam waktu sangat lama; dan Kedua, eksekutif mempunyai akses informasi yang besar dalam konteks penyusunan anggaran. Sedangkan perilaku oportunistik legislatif didorong oleh adanya keunggulan kekuasaan (discretionary power) dalam konteks memutuskan anggaran. Faktor inilah yang mendorong legislatif untuk melakukan; Pertama, berusaha memengaruhi eksekutif untuk memaksimumkan anggaran pada program-program tertentu yang dapat memuluskan jalan bagi seorang legislator untuk dapat terpilih kembali dalam pemilu berikutnya; Kedua, mendorong eksekutif untuk mengajukan anggaran yang dapat dengan mudah diserap oleh konstituennya dan tidak melalui prosedur birokrasi yang rumit. 
Penelitian sebelumnya Abdullah dan Asmara (2006), Abdullah (2012), Oktririniatmaja (2011), Suryarini (2012), dan Sularso et al (2014) menunjukkan bahwa DAU, PAD dan SiLPA berpengaruh positif terhadap perilaku oportunistik penyusunan anggaran. Penelitian tentang perilaku oportunistik penyusun anggaran sebelumnya, lebih fokus pada perilaku legislatif yang cenderung mempengaruhi alokasi anggaran untuk kepentingan politik dengan meningkatkan anggaran untuk belanja infastruktur dan belanja DPRD. Namun mengamati fenomena yang terjadi terkait proses penyusunan APBD yang merupakan proses bersama antara legislatif dan eksekutif, peneliti tertarik untuk meneliti perilaku oportunistik yang terjadi akibat interaksi antara kedua pihak yang didasari adanya hubungan keagenan.

Fenomena perilaku penyusun anggaran sangat menarik untuk diteliti lebih lanjut, karena meskipun aturan formal tentang mekanisme penyusunan APBD telah dirancang sedemikian rupa, namun pada prakteknya masih terjadi beberapa penyimpangan. Meningkatnya kasus korupsi merupakan salah satu indikasi terjadinya perilaku oportunistik yang dilakukan penyusun anggaran (Mauro,1998). Sejalan dengan hal tersebut, Sujaie (2013) menegaskan bahwa peningkatan belanja hibah dan bantuan sosial juga menunjukkan telah terjadi perilaku oportunistik penyusun anggaran. Fenomena perilaku penyusun anggaran menarik untuk diteliti lebih lanjut, karena masih ditemui beberapa penyimpangan meskipun secara formal mekanisme penyusunan anggaran telah diatur dalam Undang-Undang. Penyimpangan yang ditemukan seperti modifikasi alokasi anggaran untuk kepentingan politis, memasukkan usulan proyek besar dengan harapan mendapat kompensasi fee project (Parwati et. al, 2015).

Dengan demikian tujuan peneliatian ini adalah untuk menganalisis pengaruh pendapatan asli daerah dan Flypaper Effect terhadap perilaku oportunistik penyusun anggaran pada kabupaten/kota di Maluku. Diharapkan penelitian ini memberikan manfaat bagi aparatur penyusun anggaran untuk meminimalisir perilaku oportunis dalam penyusunan anggaran.

\section{METODE}

Metode dasar yang digunakan dalam penelitian ini adalah metode eksplanasi yaitu berusaha menjelaskan hubungan satu variabel dengan variabel yang lain, dengan menyoroti hubungan yang telah dirumuskan sebelumnya (Nazir, 2003). Penelitian ini dilaksanakan pada pemerintah daerah kabupaten/kota di Maluku. Jenis data yang digunakan dalam penelitian ini adalah data sekunder dalam bentuk data panel berupa data time series dari tahun 2014 sampai 2020 dan data cross section yakni data 11 kabupaten/kota. Data panel (pooled data) atau data longitudinal merupakan gabungan antara data cross section dan data time series. Data cross section adalah data yang memiliki banyak unit analisis yang dikumpulkan dalam satu waktu, sedangkan data time series merupakan data yang dikumpulkan dari waktu ke waktu terhadap satu unit pengamatan. Data panel digunakan untuk melakukan analisis empirik yang tidak dapat dilakukan hanya menggunakan data cross section atau time series. 
Penelitian ini menggunakan alat analisis yaitu regresi data panel. Menurut Gujarati dalam Ghozali (2005) bahwa analisis regresi pada dasarnya adalah studi mengenai ketergantungan variabel dependen dengan satu atau lebih variabel independen dengan tujuan mengestimasi dan atau memprediksi rata-rata populasi atau nilai rata-rata variabel dependen berdasarkan nilai variabel independen yang diketahui. Hasil analisis adalah berupa koefisien untuk masing-masing variabel independen. Koefisien ini diperoleh dengan cara memprediksi nilai variabel dependen dengan suatu persamaan. Data penelitian diolah menggunakan bantuan software SPSS versi 23.

\section{HASIL DAN PEMBAHASAN}

\section{Analisis Statistik Deskriptif}

Statistik deskriptif memberikan gambaran atau deskripsi suatu data yang dilihat dari nilai rata-rata (mean), standar deviasi serta nilai maksimum dan minimum. Berikut ini disajikan hasil analisis statistik deskriptif variabel penelitian pada Tabel 1.

Tabel 1 Statistik Deskriptif Variabel Penelitian

\begin{tabular}{cccc}
\hline Deskriptif Statistik & PAD & Flypaper Effect & $\begin{array}{c}\text { Perilaku Oportunistik } \\
\text { Penyusun Anggaran }\end{array}$ \\
\hline Minimum & $-43.224,76$ & $-175.369,54$ & $-147.287,81$ \\
Maksimum & $97.173,26$ & $259.996,47$ & $222.569,54$ \\
Rata-Rata & $8.042,13$ & $26.816,15$ & $34.182,53$ \\
Standar Deviasi & $17.321,69$ & $45.070,09$ & $79.830,72$ \\
Valid N (listwise) & 77 & 77 & 77 \\
\hline
\end{tabular}

Sumber: Data sekunder diolah, 2021

Berdasarkan Tabel 1, terlihat nilai minimum, nilai maksimum, nilai rata-rata, dan standar deviasi dari tahun 2014 sampai tahun 2020 untuk komponen pendapatan asli daerah kabupaten/kota di Maluku dimana hasil analisis statistik deskriptif menunjukkan bahwa selama periode penelitian terlihat bahwa nilai spread terendah pendapatan asli daerah sebesar (Rp. 43.224,76 juta) dan nilai spread tertinggi pendapatan asli daerah sebesar Rp. 97.173,26 juta dengan nilai spread rata-rata pendapatan asli daerah sebesar Rp. 8.042,13 juta dan nilai spread standar deviasi sebesar Rp. 17.321,69 juta. Nilai spread minimum komponen Flypaper Effect kabupaten/kota di Maluku periode 2014 sampai 2020 sebesar (Rp. 175.369,54 juta), nilai spread maksimumnya sebesar Rp. 259.996,47 juta, nilai spread rata-rata sebesar Rp. 26.816,15 juta dan nilai spread standar deviasi sebesar Rp. 45.070,09 juta. Nilai spread minimum komponen oportunistik penyusun anggaran kabupaten/kota di Maluku periode 2014 sampai 2020 sebesar (Rp. 147.287,81 juta), nilai spread maksimumnya sebesar Rp. 222.569,54 juta, nilai 
spread rata-rata sebesar Rp. 34.182,53 juta, dan nilai spread standar deviasi sebesar Rp. 79.830,72 juta.

\section{PENGUJIAN ASUMSI KLASIK}

\section{Uji Multikolinearitas}

Uji multikolinearitas bertujuan untuk menguji apakah model regresi ditemukan adanya korelasi antar variabel bebas (independent). Model regresi yang baik seharusnya tidak terjadi korelasi diantara variabel independent. Uji multikolinearitas dapat dilakukan dengan menghitung nilai tolerance dan nilai VIF (Variance Inflating Factor). Jika nilai tolerance $>0.10$ dan VIF $<10$, maka dapat disimpulkan tidak terdapat multikolinearitas, begitu juga sebaliknya yaitu jika nilai tolerance <.0,10 dan VIF > 10, maka dapat disimpulkan terdapat multikolinearitas. Hasil penelitian yang baik menunjukkan tidak terjadi multikolinearitas pada hasil penelitian. Berikut ini disajikan hasil pengujian asumsi multikolinearitas pada Tabel 2.

Tabel 2 Hasil Pengujian Asumsi Multikolinearitas

\begin{tabular}{cccc}
\hline Variabel & Tolerance & VIF & Keterangan \\
\hline Pendapatan Asli Daerah (X1) & 0,997 & 1,003 & Non Multikolinearitas \\
Flypaper Effect (X2) & 0,997 & 1,003 & Non Multikolinearitas \\
\hline
\end{tabular}

Sumber: Data sekunder diolah, 2021

Berdasarkan Tabel 2, terlihat bahwa variabel penelitian menunjukkan tidak terjadinya multikolinearitas karena nilai tolerance $>0,10$ dan VIF $<10$.

\section{Uji Heteroskedastisitas}

Untuk mendeteksi ada tidaknya heteroskedastisitas dengan melihat pola titik-titik pada Scatterplot regresi. Jika titik-titik menyebar dengan pola yang tidak jelas di atas dan di bawah angka 0 pada sumbuh Y maka tidak terjadi masalah heteroskedastisitas. Berikut ini disajikan hasil Scatterplot output regresi pada Gambar 1.

Berdasarkan Gambar 1 Scatterplot, dapat diketahui bahwa titik-titik menyebar dengan pola yang tidak jelas di atas dan di bawah angka 0 pada sumbu $Y$, maka pada model regresi tidak terjadi masalah heteroskedastisitas.

Selain itu, untuk memperkuat hasil analisis ada tidaknya heteroskedastisitas, dapat digunakan uji Glejser. Berikut ini disajikan hasil pengujian heteroskedastisitas (uji Glejser) pada Tabel 3. 


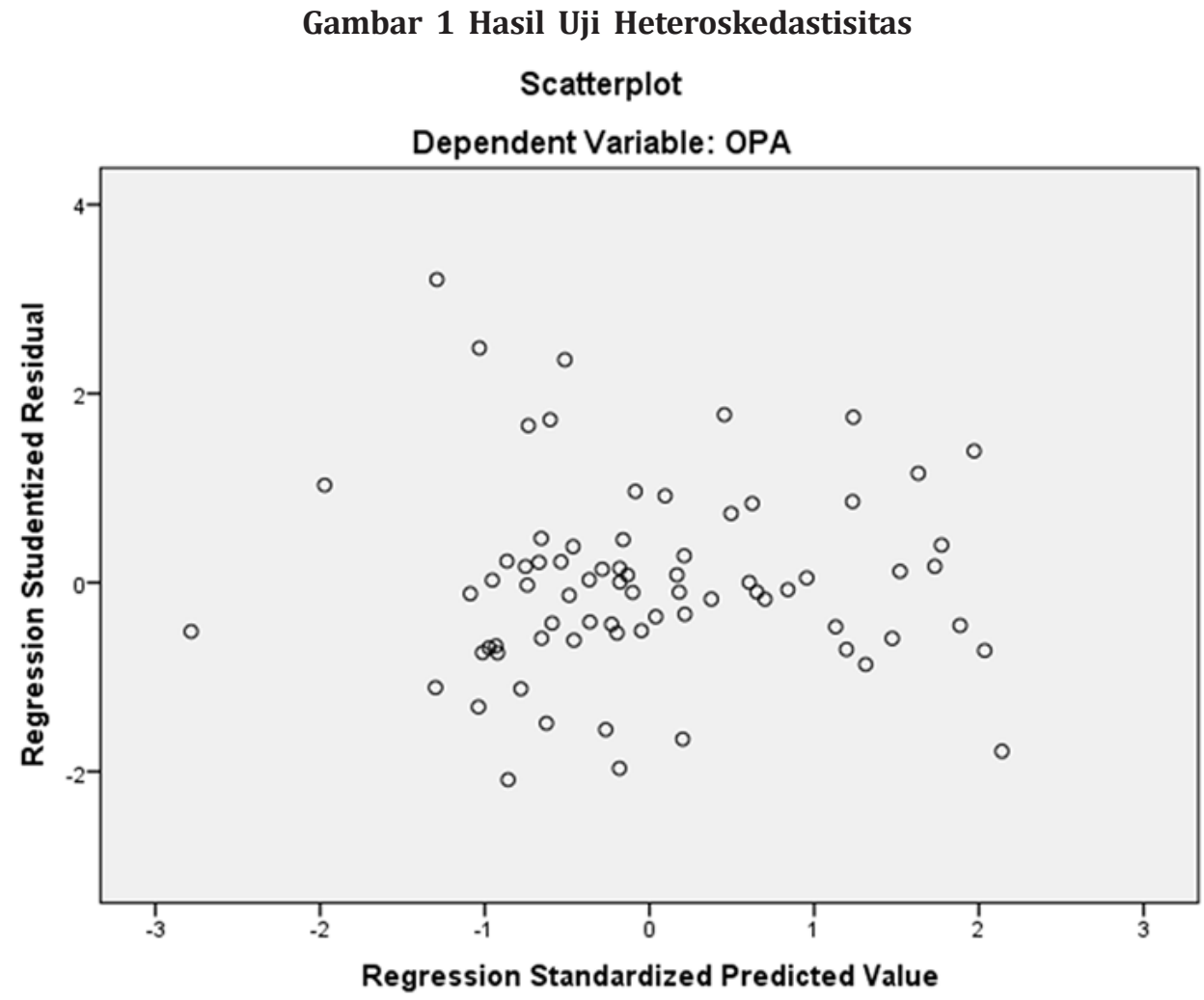

Sumber: Data Sekunder Diolah, 2021

Tabel 3 Hasil Pengujian Heteroskedastisitas

\begin{tabular}{ccc}
\hline Variabel & Sig. & Keterangan \\
\hline Pendapatan Asli Daerah (X1) & 0,951 & Non Heteroskedastisitas \\
Flypaper Effect (X2) & 0,114 & Non Heteroskedastisitas \\
\hline
\end{tabular}

Sumber: Data sekunder diolah, 2021

Hasil penelitian menunjukkan bahwa probabilitas variabel independen pada persamaan penelitian $>0,05$, sehingga dapat disimpulkan bahwa data penelitian tidak menunjukkan adanya gejala heteroskedastisitas.

\section{Uji Normalitas}

Untuk menguji data berdistribusi normal atau tidak dilihat dari grafik Normal $P-P$ Plot of regression standarized residual. Jika data menyebar disekitar garis diagonal dan mengikuti arah diagonal, maka model regresi memenuhi asumsi normalitas. Sedangkan, jika data menyebar jauh dari garis diagonal atau tidak mengikuti arah diagonal, maka model regresi tidak memenuhi asumsi normalitas. Berikut ini disajikan hasil uji normalitas pada Gambar 2. 


\section{Gambar 2 Hasil Uji Normalitas}

\section{Normal P-P Plot of Regression Standardized Residual}

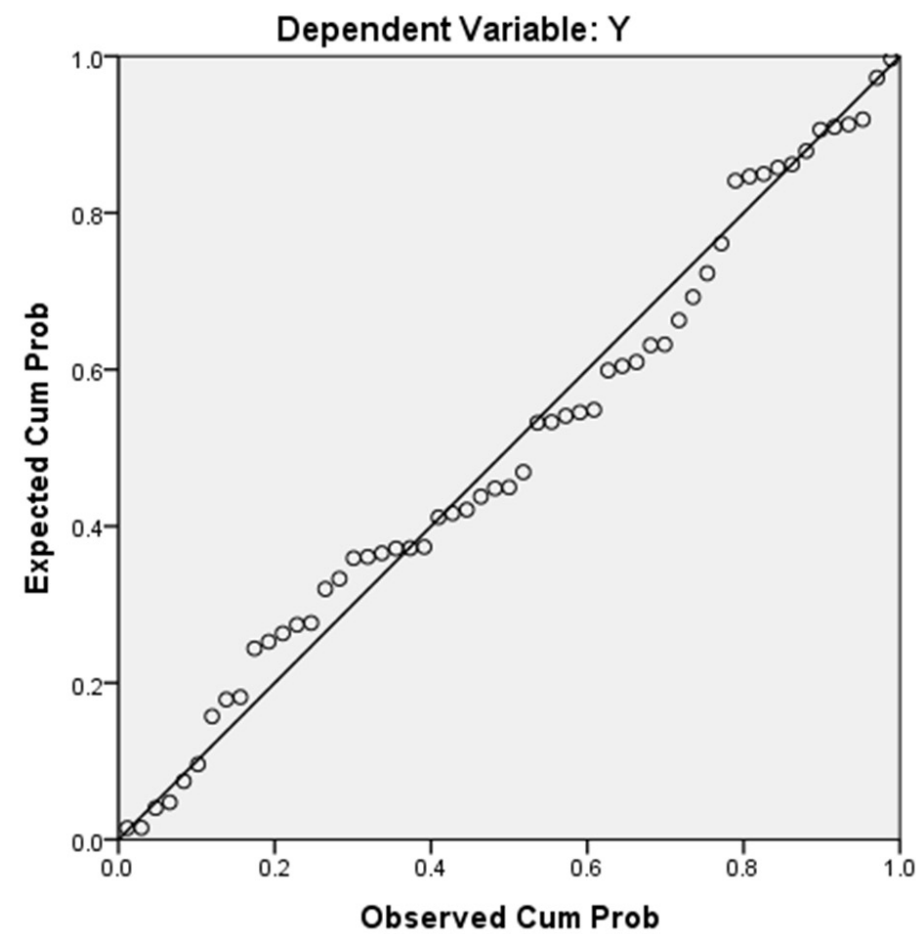

Sumber: Data Sekunder Diolah, 2021

Selain menggunakan plot seperti pada Gambar 2, untuk akurasi uji normalitas dalam penelitian ini, dilakukan pula dengan menggunakan uji Kolmogorov-Smirnov (Monte Carlo). Hasil analisis data menggunakan SPSS 23 diperoleh nilai Sig. Kolmogorov Smirnov (Monte Carlo) sebesar 0,119. Nilai ini telah memenuhi syarat uji normalitas, yaitu jika hasil pengujian diperoleh nilai Sig $>0.05$, maka asumsi normalitas terpenuhi. Dengan demikian data penelitian ini terdistribusi normal.

\section{ANALISIS REGRESI DATA PANEL Uji Simultan (Uji F)}

Untuk mengetahui apakah semua variabel independen yang dimasukkan dalam model mempunyai pengaruh secara bersama-sama (simultan) terhadap variabel dependen, maka dilakukan Uji Simultan atau Uji F (Ghozali, 2005). Berikut ini disajikan hasil Uji Simultan F pada Tabel 4 .

Tabel 4 Hasil Uji Simultan (Uji F)

\begin{tabular}{lllcccc}
\hline & Model & Sum of Squares & df & Mean Square & F & Sig. \\
\hline 1 & Regression & 85891720134,680 & 2 & 42945860067,340 & 7,836 &, 001 \\
& Residual & 383623211151,437 & 70 & 5480331587,878 & & \\
& Total & 469514931286,117 & 72 & & \\
\hline
\end{tabular}


Berdasarkan hasil pengolahan data berdasarkan Tabel 4, uji simultan menunjukkan bahwa nilai $\mathrm{F}$ hitung 7,836 $>$ nilai $\mathrm{F}$ tabel 3,12 ( $\alpha=5$ persen, $\mathrm{df}_{1}=2$ dan $\mathrm{df}_{2}=77$ ), dengan angka signifikansi sebesar 0,001 $<0,05$, sehingga disimpulkan bahwa variabel Pendapatan Asli Daerah (X1) dan Flypaper Effect (X2) secara bersama-sama berpengaruh terhadap Perilaku Oportunistik Penyusun Anggaran (Y).

\section{Uji Parsial (Uji t)}

Berikut ini disajikan hasil uji parsial (Uji t) untuk melihat pengaruh Pendapatan Asli Daerah (X1) dan Flypaper Effecy (X2) terhadap Perilaku Oportunistik Penyusun Anggaran (Y) pada Tabel 5.

Tabel 5 Hasil Analisis Regresi Data Panel

\begin{tabular}{cccccc}
\hline $\begin{array}{c}\text { Hubungan } \\
\text { Antar Variabel }\end{array}$ & $\begin{array}{c}\text { Koefisien } \\
\text { Regresi }\end{array}$ & $\begin{array}{c}\text { Standard } \\
\text { Error }\end{array}$ & t-Statistik & Prob. & Keterangan \\
\hline $\mathrm{X}_{1} \rightarrow \mathrm{Y}$ & 2,006 & 0,712 & 2,817 & 0,006 & Signifikan \\
$\mathrm{X}_{2} \rightarrow \mathrm{Y}$ & 0,922 & 0,306 & 3,013 & 0,004 & Signifikan \\
\hline
\end{tabular}

Sumber: Data Sekunder Diolah, 2021

Berdasarkan hasil estimasi pada Tabel 5, maka terlihat bahwa nilai t hitung 2,817 > nilai t tabel 1,991 ( $\alpha=5$ persen, $d f=77$ ), dengan angka signifikansi sebesar $0,006<0,05$, sehingga disimpulkan bahwa variabel pendapatan asli daerah (X1) berpengaruh signifikan terhadap perilaku oportunistik penyusun anggaran (Y). Nilai koefisien regresi sebesar 2,006 bertanda positif menunjukkan hubungan yang searah. Artinya, meningkatnya pendapatan asli daerah sebesar 1 persen akan meningkatkan perilaku oportunistik penyusun anggaran sebesar 2,006.

Variabel Flypaper Effect memiliki nilai t hitung 3,013 > nilai t tabel 1,991 $(\alpha=5$ persen, df=77), dengan angka signifikansi sebesar 0,004 < 0,05, sehingga disimpulkan bahwa variabel Flypaper Effect (X2) berpengaruh signifikan terhadap perilaku oportunistik penyusun anggaran (Y). Nilai koefisien regresi sebesar 0,922 bertanda positif menunjukkan hubungan yang searah. Artinya, meningkatnya Flypaper Effect sebesar 1 persen akan meningkatkan perilaku oportunistik penyusun anggaran sebesar 0,922.

Berdasarkan hasil analisis data sebagaimana terlihat pada Tabel 5, dapat dijelaskan bahwa variabel pendapatan asli daerah memiliki nilai probabilitas sebesar 0,006 lebih kecil dari nilai signifikansi 0,05. Dari nilai tersebut dapat disimpulkan bahwa variabel pendapatan asli daerah memberikan pengaruh signifikan terhadap perilaku oportunistik penyusun anggaran. Sedangkan nilai koefisien sebesar 2,006 bertanda positif menunjukkan bahwa pendapatan asli daerah berbanding lurus dengan perilaku oportunistik penyusun anggaran. Artinya, setiap kenaikan pendapatan asli daerah sebesar 1 persen akan mendorong terjadinya perilaku oportunistik penyusun anggaran sebesar 2,006 persen. 
Temuan hasil penelitian ini konsisten dengan penelitian Musripah (2014), Adi (2014), Sularso (2014), dan Yusuf, et. al (2020) yang menyatakan bahwa pendapatan asli daerah berpengaruh positif pada perilaku oportunistik penyusun anggaran., sedangkan bertentangan dengan hasil penelitian Megasari (2015) yang menemukan bahwa Megasari (2015) yang menemukan bahwa PAD berpengaruh positif namun tidak signifikan terhadap perilaku oportunistik penyusun anggaran.

Hal ini disebabkan karena jumlah pendapatan asli daerah yang rendah membawa kecenderungan dampak psikologis perilaku pegawai dalam melaksanakan tugasnya. Akibat dari tingkat kesejahteraan pegawai yang semakin kecil, sehingga membuka peluang untuk melakukan perilaku oportunistik penyusun anggaran dalam bentuk tindakan-tindakan ilegal. Pelaksanaan desentralisasi di Indonesia melalui Otonomi Daerah membawa banyak perubahan dalam sistem pemerintahan. Namun, setelah berjalan belasan tahun, lebih dari 60 persen daerah otonomi dinyatakan gagal oleh Kementerian Dalam Negeri RI. Kegagalan ini tampak berdasarkan indikator bahwa daerah otonomi tidak bisa meningkatkan kesejahteraan rakyat, PAD tidak bertambah dan malah jadi beban anggran bagi daerah induk yang dimekarkan serta makin banyaknya tersangka korupsi (Suadi, 2014).

Penyalahgunaan anggaran di dalam otonomi daerah menjadi sorotan khusus karena ketidakberhasilan dalam mensejahterakan masyarakat dan meningkatkan PAD. Selain itu, jika dihubungkan dengan teori keagenan dalam penganggaran antara eksekutif dan legislatif merupakan satu kesatuan yang sangat sulit dipisahkan. Eksekutif sebagai agen bagi legislatif dan publik (dual accountability), sedangkan legislatif merupakan agen bagi publik. Eksekutif sebagai agen cenderung menjadi budget maximizer karena melihat kesempatan untuk melakukan perilaku oportunistik berupa moral hazard dan adversed selection (Abdullah dan Asmara, 2006).

Selain itu, pengaruh variabel Flypaper Effect memiliki nilai probabilitas sebesar 0,004 lebih kecil dari 0,05. Dari nilai tersebut dapat disimpulkan bahwa variabel Flypaper Effect memberikan pengaruh signifikan terhadap perilaku oportunistik penyusun anggaran. Sedangkan nilai koefisien sebesar 0,922 bertanda positif menunjukkan bahwa Flypaper Effect berbanding lurus dengan perilaku oportunistik penyusun anggaran. Artinya, setiap peningkatan Flypaper Effect sebesar 1 persen akan meningkatkan perilaku oportunistik penyusun anggaran sebesar 0,922 persen.

Penelitian ini mendukung hasil penelitian dari Hastuti (2011) dan Adi (2014), namun bertentangan dengan hasil penelitian Megasari (2015). Hal ini disebabkan oleh adanya respon pemerintah daerah yang berbeda terhadap jumlah transfer dana berupa dana alokasi umum (DAU) yang rendah dan jumlah pendapatan asli daerah (PAD) yang kecil sehingga memotivasi para penyusun anggaran untuk mencari celah untuk memperkaya dirinya dengan melakukan tindakan-tindakan illegal yang melanggar peraturan perundangan yang berdampak pada kerugian negara. Sehingga aspek kesejahteraan para Aparatur Sipil Negara perlu mendapatkan perhatian khusus dari pemerintah pusat maupun daerah untuk meminimalisasi perilaku oportunistik penyusun anggaran.

Perubahan posisi legislatif yang menjadi powerful menyebabkan legislatif memiliki 
power untuk merubah usulan anggaran yang diajukan eksekutif. Legislatif yang memiliki hak untuk meminta pertanggungjawaban dan mengadakan penyelidikan terhadap eksekutif menjadi sangat berwibawa dalam proses anggaran. Artinya, legislatif sebagai agen dari publik berpeluang melakukan moral hazard (Von Hagen dalam Abdullah, 2012). Hal ini merupakan suatu penyalahgunaan discretionary power dengan melanggar kesepakatan (agreement) yang telah dibuat. Stiglitz dalam Abdullah (2012), menyatakan bahwa sumber dana mempengaruhi kehati-hatian seorang agen dalam membuat kebijakan penggunaannya. Dalam hubungan antarpemerintah, perilaku ini disebut Flypaper Effect, yakni adanya perbedaan respons belanja atas sumber pendapatan atau penerimaan pemerintah. Dalam konteks peran legislatif dalam penganggaran, adanya motif self-interest akan mempengaruhi pengalokasian dana di dalam anggaran. Fenomena Flypaper Effect membawa implikasi lebih luas bahwa transfer akan meningkatkan belanja pemerintah daerah yang lebih besar daripada penerimaan transfer itu sendiri (Turnbull dalam Megasari, 2015). Flypaper Effect merupakan fenomena dalam penelitian ini. Maimunah dalam Megasari (2015) menyatakan bahwa Flypaper Effect disebut sebagai suatu kondisi yang terjadi saat pemerintah daerah merespon (belanja) lebih banyak (lebih boros) dengan menggunakan dana transfer (grants) yang diproksikan dengan DAU dari pada menggunakan kemampuan sendiri, diproksikan dengan PAD. Berdasarkan uraian di atas maka dapat dirumuskan hubungan antara Flypaper Effect terhadap perilaku oportunistik penyusun anggaran, seperti di bawah ini. Hubungan antara Flypaper Effect dengan Perilaku Oportunistik Penyusun Anggaran adalah positif, artinya semakin tinggi perilaku oportunistik penyusun anggaran, maka akan semakin besar terjadinya Flypaper Effect.

Secara simultan Pendapatan Asli Daerah dan Flypaper Effect berpengaruh positif signifikan terhadap Perilaku Oportunistik Penyusun Anggaran Kabupaten/Kota di Maluku. Perubahan PAD berpengaruh secara signifikan terhadap perilaku oportunistik legislatif (Abdullah dalam Florensia, 2009). Secara konseptual perubahan APBD akan berpengaruh terhadap belanja, namun tidak selalu seluruh tambahan pendapatan tersebut akan dialokasikan dalam belanja. Perubahan APBD menjadi sarana bagi legislatif dan eksekutif untuk merubah alokasi anggaran secara legal. Perilaku oportunistik legislatif dan eksekutif saat perubahan APBD dapat mengakibatkan terjadinya misalokasi anggaran belanja pemerintah. Proporsi PAD yang rata-rata hanya 10\% dari total penerimaan daerah memiliki kecenderungan bertambah saat perubahan anggaran. Hal ini membuka peluang bagi legislatif untuk merekomendasikan penambahan anggaran bagi program dan kegiatan yang menjadi preferensinya (Fathony, 2011). Hubungan antara Pendapatan Asli Daerah (PAD) dengan Perilaku Oportunistik Penyusun Anggaran adalah positif, artinya semakin tinggi PAD semakin tinggi perilaku oportunistik penyusun anggaran sehingga menyebabkan semakin besar terjadinya Flypaper Effect.

\section{SIMPULAN}

Berdasarkan hasil penelitian dan pembahasan yang telah dikemukakan sebelumnya, maka dapat disimpulkan beberapa hal sebagai berikut: 1) Pendapatan Asli Daerah (PAD) 
berpengaruh positif dan signifikan terhadap Perilaku Oportunistik Penyusun Anggaran Kabupaten/Kota di Maluku, hal ini bermakna bahwa semakin tinggi Pendapatan Asli Daerah, maka akan mendorong semakin tinggi perilaku Oportunistik Penyusun Anggaran; 2) Flypaper Effect berpengaruh positif terhadap Perilaku Oportunistik Penyusun Anggaran Kabupaten/Kota di Maluku, hal ini bermakna bahwa semakin tinggi jumlah Flypaper Effect yang terjadi di Kabupaten/Kota di Maluku, maka akan menyebabkan perilaku oportunistik penyusun anggaran yang semakin tinggi, dan 3) Secara simultan Pendapatan Asli Daerah (PAD) dan Flypaper Effect berpengaruh terhadap Perilaku Oportunistik Penyusun Anggaran Kabupaten/Kota di Maluku.

Dengan demikian pemerintah kabupaten/kota di Maluku perlu untuk: 1) meningkatkan Pendapatan Asli Daerah mesti menjadi perhatian serius pemerintah daerah kabupaten/kota di Maluku dalam rangka mencegah kecenderungan dampak psikologis perilaku pegawai dalam melaksanakan tugasnya yang mengarah pada perilaku oportunistik yang dapat merugikan daerah, 2) aspek kesejahteraan para Aparatur Sipil Negara perlu mendapatkan perhatian khusus dari pemerintah pusat maupun daerah untuk meminimalisasi perilaku oportunistik penyusun anggaran, dan 3) pemerintah daerah kabupaten/kota di Maluku mesti merespons dana transfer dari pemerintah pusat untuk diprioritaskan pada program/ kegiatan yang menambah pendapatan asli daerah untuk mencegah perilaku oportunistik penyusun anggaran.

\section{PUSTAKA ACUAN}

Abdullah, S. 2012. Perilaku Oportunistik Legislatif dan Faktor-Faktor Yang Mempengaruhinya: Bukti Empiris dari Penganggaran Pemerintah Daerah di Indonesia. Ringkasan Disertasi. Yogyakarta: Universitas Gajah Mada.

Abdullah, S. dan Asmara, J.A., 2006. Perilaku Oportunistik Legislatif Dalam Penganggaran Daerah: Bukti Empiris atas Aplikasi Agency Theory di Sektor Publik. Makalah Simposium Nasional Akuntansi 9. Padang: 23-26 Agustus 2006.

Adi Putra, I Made Pradana, 2014. Flypaper Effect pada DAU dan PAD terhadap Belanja Daerah di Kabupaten Karangasem.

Diah Ayu Kusumadewi dan Arief Rahman, 2007. Flypaper Effect pada Dana Alokasi Umum (DAU) dan Pendapatan Asli Daerah (PAD) Terhadap Belanja Daerah pada Kabupaten/ Kota Di Indonesia. Jurnal JAAI Volume 11 Nomor 1, Halaman 67-80.

Fathony, A. D. dan Abdul Rohman. 2011. Pengaruh Pendapatan Asli Daerah, Sisa Lebih Perhitungan Anggaran dan Dana Alokasi Umum Terhadap Perilaku Oportunistik Penyusun Anggaran (Studi Kasus Kabupaten/Kota di Provinsi Jawa Tengah).

Florensia, T. M. 2009. Perilaku Oportunistik Legislatif Dalam Penganggaran Daerah: Bukti Empiris atas Aplikasi Agency Theory di Sektor Publik, Tesis Program Pasca Sarjana Magister Sains Ilmu Ekonomi Universitas Gajah Mada.

Ghozali, Imam. 2005. Aplikasi Analisis Multivariate dengan SPSS. Semarang: Badan Penerbit UNDIP. 
Gregorius N. Masdjojo dan Sukartono, 2009. Pengaruh Pendapatan Asli Daerah dan Dana Perimbangan Terhadap Belanja Daerah serta Analisis Flypaper Effect Kabupaten/Kota di Jawa Tengah Tahun 2006-2008. Jurnal TEMA Volume 6 Edisi 1 Maret, Halaman 32-50.

Halim, Abdul. 2002. Analisis Varian Pendapatan Asli Daerah Dalam Laporan Perhitungan Anggaran Pendapatan dan Belanja Daerah Kabupaten/Kota di Indonesia. Universitas Gadjah Mada. Disertasi.

Hastuti, Indhi, 2010. Analisis Flypaper Effect, Dana Alokasi Umum, Pendapatan Asli Daerah dan Kinerja SKPD di Kota Semarang.

Jumaidi, L.T.2014. Perilaku Legislatif dalam Praktik Penganggarand engan Pendekatan Nilai-Nilai Kearifan Lokal. Jurnal Simposium Nasional Akuntansi 17 Mataram Lombok 24-27 September 2014.

Mauro, Paulo, 1998. "Corruption and the Composition of Government Expenditure".

Megasari Ida Ayu Gede Sutha. 2015, Pengaruh Pendapatan Asli Daerah, Selisih Perhitungan Anggaran dan Flypaper Effect Pada Perilaku Oportunistik Penyusun Anggaran. Tesis Program Pasca Sarjana Magister Akuntansi Universitas Udayana.

Musripah, Siti, 2011. Pengaruh Perubahan PAD, SiLPA, dan DAU Terhadap Perilaku Oportunistik Penyusun Anggaran (Studi pada Kabupaten/Kota di Provinsi Jawa Tengah).

Nazir, M. 2003. Metode Penelitian. Jakarta : Ghalia Indonesia.

Oktririniatmaja, R. 2011. Pengaruh Pendapatan Asli Daerah, Dana Alokasi Umum dan Dana Alokasi Khusus terhadap Pengalokasian Anggaran Belanja Modal dalam Anggaran Pendapatan dan Belanja Daerah Pada Pemerintah Daerah Kabupaten/Kota di Pulau Jawa, Sulawesi Tenggara dan Nusa Tenggara. E-Journal Universitas Sebelas Maret.

Parwati Sayu Made et al. 2015. Perilaku Oportunistik Penyusun Anggaran. Jurnal Ilmiah Akuntansi dan Bisnis, Vol. 10. No.2, Juli 2015.

Raghunan dan, M. Ramgulam, N and Raghunan dan, K.2012. Examining the Behavioural Aspects of Budgeting with Particular Emphasis on Public Sector/Service Budgets. International Journal of Business and Social Science, 3(14).

Smith, Robert W. \& Mark Bertozzi. 1998. Principals and agents: An explanatory model of public budgeting. Journal of Public Budgeting, Accounting and Financial Management (Fall): 325-353.

Sujaie, A. F. 2013. Oportunisme Perumus Kebijakan Anggaran dalam Penyusunan APBD Provinsi Jawa Timur Tahun 2013: Fenomena dalam Pelaksanaan Belanja Hibah dan Bansos. Ejournal UGM.

Sularso, H., Restianto, Y.E. dan Istiqomah, A.E. 2014. Determinan Perilaku Oportunistik Penyusunan Anggaran (Studipada Kabupaten/KotadiJawa Tengah). Jurnal Simposium Nasional Akuntansi1 7 Mataram Lombok 24-27 September2014.

Suryarini, T. 2012. Perilaku Oportunistik Legialtaif dalam Penganggaran Daerah: Bukti Empirisatas Aplikasi Agency Theory di Sektor Publik. Jurnal Review Akuntansi dan Keuangan, Vol. 2 No. 1 April 2012. 
Wahyu Winarno, Wing. 2009. Analisis Ekonometrika dan Statistika dengan Eviews. Badan Penerbit: UPP STIM YKPN, Yogyakarta.

Widodo, Pambudi Tri. 2007. Flypaper Effect pada Dana Alokasi UMUM (DAU) dan Pendapatan Asli Daerah (PAD) terhadap Belanja Daerah pada Kabupaten/Kota di Bali. (Studi pada Kabupaten/Kota di Bali). Skripsi Sarjana (tidak dipublikasikan). Yogyakarta : FE UII.

Yuhertiana, I. 2003. Principal-Agent Theory Dalam Proses Perencanaan Anggaran Sektor Publik. Kompak - Jurnal Akuntansi, Manajemen dan Sistem Informasi (SeptemberDesember): 403-42.

Yusuf Jaya Saputra,2019. Pengaruh DAU, PAD, SILPA, Jenis Dan Letak Pemerintahan Terhadap Perilaku Oportunistik Penyusun Anggaran di Kabupaten/Kota Se-Sulawesi Tenggara. Jurnal Progres Ekonomi Pembangunan (JPEP), Volume 5, Nomor 1. 